\title{
Efektivitas Pengasuhan Positif untuk Menurunkan Stres Pengasuhan Ibu Bekerja dengan Anak Usia Prasekolah
}

\author{
The Effectiveness of Positive Parenting in Reducing Parenting Stress \\ of Working Mothers with Preschool Children
}

\author{
Meinita Fitriana Sari ${ }^{1}$, Budi Andayani² \\ 1,2Fakultas Psikologi, Universitas Gadjah Mada
}

\author{
Submitted 3 September 2021 Accepted 21 October $2021 \quad$ Published 30 October 2021
}

\begin{abstract}
Working mothers with preschool age children have limited interaction time and attachment with their children. Consequently, their children tend to show behavior that is not in line with parental expectations. Poor quality of interaction between the environment of parents and children can cause parents to experience a period of stress in parenting, or commonly called parenting stress. The purpose of this research was to measure the effectiveness of positive parenting programs to reduce parenting stress level of working mothers with preschool children by increasing their parenting efficacy. The hypothesis in this study was that parenting efficacy training can reduce the level of parenting stress. A quasi experiment with untreated control group pretest-posttest design was adopted for this study. Ten people were involved as research participants. Data analysis used non-parametric statistical analysis of the Mann Whitney U Test to measure differences in parenting stress scores and parenting efficacy before and after the intervention. The results showed that the positive parenting training program was effective in reducing parenting stress in working mothers (posttest-pretest $Z=-2.803$ and $p=0.005(p<0.05)$ ). The qualitative results show that there are changes in parenting practices for working mothers, including involvement, monitoring and habituation of positive behavior.
\end{abstract}

Keywords: parenting stress; positive parenting training; working mother

Abstrak. Ibu bekerja dengan anak usia prasekolah cenderung memiliki waktu interaksi serta kelekatan yang kurang dengan anak-anak mereka. Oleh karena itu, anak cenderung meniru atau melakukan tindakan atau kata-kata yang tidak sesuai dengan harapan orang tua. Interaksi antara lingkungan orang tua dan anak yang kurang baik dapat menyebabkan orang tua mengalami masa stres, atau biasa disebut stres pengasuhan. Tujuan penelitian yang dilakukan adalah untuk mengukur efektivitas program pengasuhan positif untuk menurunkan tingkat stres pengasuhan dengan meningkatkan efikasi pengasuhan pada ibu bekerja dengan anak usia prasekolah. Hipotesis dalam penelitian ini adalah pelatihan efikasi pengasuhan dapat menurunkan tingkat stres pengasuhan. Metode yang digunakan dalam penelitian ini adalah eksperimen kuasi dengan untreated control group pretest posttest design dengan peserta sejumlah sepuluh orang. Analisis data menggunakan analisis statistik non parametric Mann Whitney U Test untuk mengukur perbedaan skor stres pengasuhan dan efikasi pengasuhan sebelum dan sesudah intervensi dilakukan. Hasil penelitian membuktikan bahwa program pelatihan pengasuhan positif efektif dalam menurunkan stres pengasuhan pada ibu bekerja (posttest-pretest $Z=-2,803$ dan $p=0,005(p<0,05)$ ). Hasil kualitatif menunjukkan adanya perubahan dalam praktik pengasuhan pada ibu bekerja meliputi keterlibatan, pemantauan, serta pembiasaan perilaku positif.

Kata kunci: ibu bekerja; pelatihan pengasuhan positif; stres pengasuhan 
Pengasuhan buruk pada anak usia dini menyebabkan kemampuan sosial dan bermain interaktif anak lebih buruk dan bersikap agresif dan disruptif secara impulsif, sehingga membuat mereka dijauhi oleh teman sebaya (Davies, 2011). Peningkatan pengasuhan orang tua yang memiliki anak usia dini penting dilakukan sebagai upaya prevensi terhadap masalah yang akan muncul pada masa dewasa dan sebagai faktor protektif terhadap anak agar anak dapat tumbuh dan berkembang secara optimal (Permata, 2017).

Keberhasilan pelaksanaan tugas pengasuhan anak dipengaruhi salah satunya oleh faktor lingkungan. Interaksi antara lingkungan dan orang tua yang kurang baik dapat membuat orang tua mengalami masa stres pada saat pelaksanaan pengasuhan pada anak. Tuntutan yang banyak pada ibu, stres dalam pengasuhan, dan kesulitan dalam menghadapi masalah perilaku pada anak dapat memengaruhi fisik dan kesejahteraan psikologis orang tua sehingga dapat menurunkan kualitas hidup ibu (Maryanti, 2017). Turut bekerja dan mengambil peran sebagai pencari nafkah ditambah dengan tanggung jawab untuk mengurus dan membesarkan anak rentan membuat ibu menjadi stres. Ibu yang bekerja seringkali mengalami stres akibat kekurangan waktu (Sulaiman, 2017).

Menurut Jackson (dalam Deater-Deckard, 2004) penyebab utama stres pengasuhan pada ibu adalah perilaku dan perkembangan anak. Kesimpulan dari hasil studi pendahuluan yang dilakukan oleh peneliti yaitu ditemukan beberapa persoalan yang dihadapi oleh ibu bekerja dengan anak usia prasekolah. Persoalan yang dihadapi oleh ibu bekerja dengan anak usia prasekolah menurut hasil studi pendahuluan antara lain kurangnya waktu interaksi dengan anak, kelekatan yang kurang hangat dengan anak serta anak cenderung meniru tindakan atau pembicaraan yang tidak sesuai dengan harapan orang tua.

Stres pengasuhan memiliki kaitan erat dengan efikasi pengasuhan (parenting self efficacy). Hasil temuan penelitian Jonez dan Prinz (2005) diantaranya menjelaskan bahwa efikasi orang tua akan menurun ketika situasi stres muncul pada orang tua. penuh tekanan yang terjadi pada pelaksanaan tugas pengasuhan anak. Efikasi diri orang tua dan stres pengasuhan mengalami perubahan yang signifikan setelah orang tua mengikuti program pelatihan pengasuhan. Program positive parenting program (Triple $P$ ) adalah salah satu program pelatihan pengasuhan yang terbukti efektif dapat mengurangi stres pengasuhan (Sanders dalam Pouretemad et al., 2009) dan mengurangi permasalahan perilaku dan emosional anak (Leung et al., 2003; Sanders et al., 2008). Program pengasuhan positif (Triple $P$ ) yang dilakukan di Indonesia menunjukkan adanya penurunan masalah perilaku anak, praktik pengasuhan disfungsional, dan stres orang tua (Sumargi \& Morawska, 2015b).

Tujuan penelitian ini adalah untuk mengetahui serta menguji efektivitas program pengasuhan positif pada penurunan tingkat stres pengasuhan dengan meningkatkan efikasi pengasuhan pada ibu bekerja yang memiliki anak usia prasekolah. Manfaat penelitian yang diharapkan adalah program pengasuhan positif yang dilakukan dapat menjadi salah satu acuan bagi orang tua serta praktisi sebagai salah satu upaya untuk 
menurunkan stres pengasuhan serta upaya preventif terjadinya perilaku negatif pada anak di masa yang akan datang. Hipotesis dalam penelitian ini adalah pelatihan pengasuhan positif dapat memengaruhi efikasi pengasuhan sehingga dapat menurunkan tingkat stres pengasuhan pada ibu bekerja yang memiliki anak usia prasekolah.

\section{Metode}

\section{Desain penelitian}

Penelitian ini menggunakan pendekatan kuantitatif dengan metode eksperimen kuasi (quasi experiment). Rancangan yang digunakan dalam penelitian ini adalah rancangan untreated control group design with pretest and posttest. Modul yang digunakan dalam penelitian ini merupakan modifikasi modul dari modul pelatihan pengasuhan positif yang disusun oleh Sanders (1999) serta modul yang digunakan pada penelitian validasi modul pengasuhan positif untuk meningkatkan efikasi diri ibu tunggal dalam pengasuhan anak (Pristanti 2016).

Variabel tergantung (dependent variable) dalam penelitian ini adalah stres pengasuhan. Stres pengasuhan merupakan serangkaian proses yang membawa pada kondisi psikologis yang tidak disukai dan reaksi psikologis yang muncul dalam upaya beradaptasi dengan tuntutan peran sebagai orang tua.

Variabel bebas (independent variable) dalam penelitian ini adalah pelatihan pengasuhan positif (positive parenting program) pada ibu bekerja. Program pelatihan pengasuhan positif (positive parenting program) merupakan serangkaian aktivitas yang dirancang dengan tujuan meningkatkan pengetahuan dan keterampilan ibu dalam melakukan pengasuhan. Peningkatan pengetahuan dan keterampilan orang tua terutama ibu yang didapatkan melalui pelatihan pengasuhan positif diharapkan dapat menurunkan stres pengasuhan pada ibu bekerja.

Modifikasi modul yang peneliti lakukan yaitu pada penelitian ini, peneliti menambahkan sesi pengelolaan stres pada saat melakukan pengasuhan positif. Modifikasi modul lain yang peneliti lakukan adalah sebelumnya, pelaksanaan pelatihan pengasuhan positif dilakukan dalam dua kali pertemuan, sedangkan pada penelitian ini dilakukan dalam tiga kali pertemuan. Susunan materi pada modul penelitian disesuaikan dengan alur penelitian sehingga susunan materi sedikit berbeda dari modul yang menjadi dasar acuan modul penelitian peneliti. Penambahan sesi pertemuan disesuaikan dengan durasi serta mempertimbangkan kondisi partisipan penelitian. Modul pelatihan dapat dilihat di Tabel 1.

\section{Peserta penelitian}

Teknik pengambilan sampel yang digunakan dalam penelitian ini adalah purposive sampling. Partisipan dalam penelitian ini adalah sepuluh orang yang memenuhi kriteria partisipan. Kriteria partisipan dalam penelitian ini yaitu : 
1. Perempuan yang telah menikah dengan rentang usia 22-35 tahun serta memiliki anak usia prasekolah

2. Pendidikan terakhir minimal SMA serta mampu berbahasa Indonesia dengan baik secara lisan dan tertulis

3. Istri yang berperan sebagai ibu serta merupakan ibu yang bekerja di luar rumah dengan jam kerja minimal delapan jam atau dengan jam bekerja pada umumnya di Jakarta yaitu jam 8 pagi hingga jam 5 sore.

4. Memiliki anak dengan jumlah minimal satu dan maksimal tiga anak dengan rentang usia anak 1-5 tahun.

5. Mengalami stres pengasuhan kategori sedang hingga tinggi berdasarkan skala stres pengasuhan

6. Mengalami efikasi pengasuhan dengan kategori rendah hingga sedang berdasarkan Skala Efikasi Pengasuhan

7. Berdomisili di sekitar Jakarta dan Depok

8. Bersedia menjadi partisipan penelitian

Peneliti melakukan proses pelaksanaan kaji etik dengan mengirimkan aplikasi kaji etik kepada komisi etik yang terdiri dari proposal penelitian, gambaran instrumen pengumpulan data, proses pelaksanaan penelitian serta penjelasan pertanyaan lembar persetujuan etika penelitian dengan nomor 5113/UN1/FPsi/UN.1.3/SD/PT/2019.

\section{Tabel 1.}

Modul Pelatihan Pengasuhan Positif

\begin{tabular}{llll}
\hline Pertemuan & Tema & Kegiatan & Indikator keberhasilan \\
\hline 1 (2 jam 45 & Dari hati ke & Pembukaan, Perkenalan, & Peserta memahami \\
menit) & hati, Jalinan & Penyamaan persepsi dan & kontrak belajar selama \\
& cinta untuk & tujuan, kontrak belajar, sesi & pelaksanaan pelatihan. \\
& anakku & bercerita mengenai & Peserta mampu \\
& pengalaman pengasuhan serta & mengenali perilaku \\
& pengenalan materi & pengasuhan yang selama \\
& pengasuhan secara umum & ini dilakukan serta \\
& & dampak pengasuhan yang \\
& & dilakukan terhadap \\
& & perkembangan anak \\
\hline
\end{tabular}




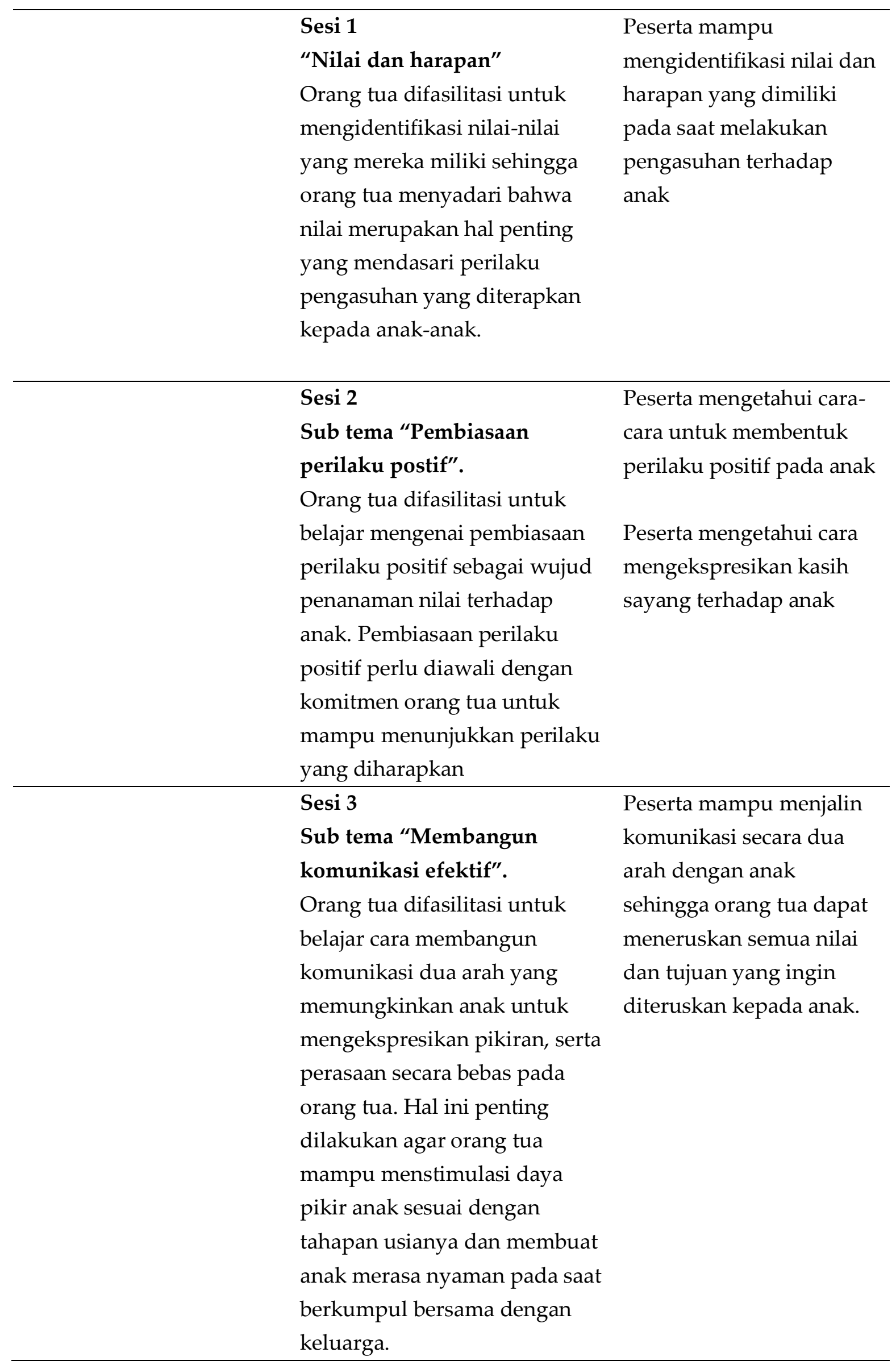




\begin{tabular}{|c|c|c|c|}
\hline & & $\begin{array}{l}\text { Sesi } 4 \\
\text { Sub tema "Anakku, aku } \\
\text { mengenal dan } \\
\text { mendukungmu". } \\
\text { Orang tua difasilitasi untuk } \\
\text { menyadari dan memahami arti } \\
\text { pentingnya mengekspresikan } \\
\text { dukungan terhadap anak. } \\
\text { Ekspresi dukungan terhadap } \\
\text { anak perlu dilakukan sehingga } \\
\text { anak merasa percaya diri } \\
\text { dalam mengembangkan minat } \\
\text { dan kemampuan yang } \\
\text { dimiliki. }\end{array}$ & $\begin{array}{l}\text { Peserta mampu } \\
\text { mengekspresikan } \\
\text { dukungan terhadap anak } \\
\text { terutama mengenai minat } \\
\text { dan kemampuan yang } \\
\text { dimiliki anak. }\end{array}$ \\
\hline $\begin{array}{l}2 \text { (2 jam } 30 \\
\text { menit) }\end{array}$ & $\begin{array}{l}\text { "Duniamu } \\
\text { duniaku" }\end{array}$ & $\begin{array}{l}\text { Sesi } 5 \\
\text { Sub tema “Mengekspresikan } \\
\text { kasih sayang”. } \\
\text { Orang tua difasilitasi untuk } \\
\text { menyadari dan memahami arti } \\
\text { pentingnya mengekspresikan } \\
\text { kasih sayang. Anak pada } \\
\text { dasarnya memiliki kebutuhan } \\
\text { untuk melihat dan mendengar } \\
\text { ekspresi kasih sayang yang } \\
\text { tulus dari orang tua sehingga } \\
\text { timbul rasa senang, nyaman } \\
\text { dan aman dalam diri mereka }\end{array}$ & $\begin{array}{l}\text { Peserta mampu } \\
\text { mengekspresikan secara } \\
\text { terbuka dan sesuai } \\
\text { mengenai kasih sayang } \\
\text { terhadap anak. }\end{array}$ \\
\hline & $\begin{array}{l}\text { "Duniamu } \\
\text { duniaku" }\end{array}$ & $\begin{array}{l}\text { Sesi } 6 \\
\text { Sub tema "Pemantauan". } \\
\text { Orang tua difasilitasi untuk } \\
\text { belajar memantau semua } \\
\text { aktivitas anak misalnya, } \\
\text { hubungan dengan teman } \\
\text { sebaya serta seluruh } \\
\text { perkembangan anak. }\end{array}$ & $\begin{array}{l}\text { Peserta mampu } \\
\text { melakukan pemantauan } \\
\text { aktif terhadap aktivitas } \\
\text { yang dilakukan anak }\end{array}$ \\
\hline
\end{tabular}




\begin{tabular}{|c|c|c|c|}
\hline & $\begin{array}{l}\text { "Duniamu } \\
\text { duniaku" }\end{array}$ & $\begin{array}{l}\text { Sesi } 7 \\
\text { Sub tema "Keterlibatan". } \\
\text { Orang tua difasilitasi untuk } \\
\text { belajar melibatkan diri dalam } \\
\text { aktivitas-aktivitas sehari-hari } \\
\text { yang dilakukan oleh anak. } \\
\text { Keterlibatan merupakan salah } \\
\text { satu cara orang tua untuk } \\
\text { menunjukkan ketertarikan, } \\
\text { serta kesediaan untuk } \\
\text { berperan aktif dalam kegiatan } \\
\text { anak sehari-hari. }\end{array}$ & $\begin{array}{l}\text { Peserta mampu } \\
\text { meningkatkan } \\
\text { pemahaman mengenai } \\
\text { keterlibatan orang tua } \\
\text { dalam aktivitas anak. } \\
\text { Peserta mampu belajar } \\
\text { mengenai cara melibatkan } \\
\text { diri dalam aktivitas yang } \\
\text { dilakukan oleh anak } \\
\text { sehari-hari. }\end{array}$ \\
\hline 3 (3 jam) & $\begin{array}{l}\text { "Ibu } \\
\text { teladan } \\
\text { anak } \\
\text { idaman" }\end{array}$ & $\begin{array}{l}\text { Sesi } 8 \\
\text { Sub tema "Pengelolaan stres" } \\
\text { Orang tua difasilitasi untuk } \\
\text { mempelajari cara pengelolaan } \\
\text { stres yang dialami selama } \\
\text { melakukan pengasuhan. } \\
\text { Pengelolaan stres yang } \\
\text { dipelajari merupakan cara } \\
\text { pengelolaan stres pada ibu } \\
\text { bekerja yang sekaligus } \\
\text { melakukan pengasuhan pada } \\
\text { anak prasekolah. }\end{array}$ & $\begin{array}{l}\text { Peserta mampu } \\
\text { mengelola stres yang } \\
\text { dialami terutama pada } \\
\text { saat pelaksanaan } \\
\text { pengasuhan. }\end{array}$ \\
\hline & $\begin{array}{l}\text { "Ibu } \\
\text { teladan } \\
\text { anak } \\
\text { idaman" }\end{array}$ & $\begin{array}{l}\text { Sesi } 9 \\
\text { Sub tema"Konsistensi". } \\
\text { Orang tua difasilitasi untuk } \\
\text { belajar menanamkan aturan } \\
\text { dan hal-hal positif secara } \\
\text { konsisten dalam pelaksanaan } \\
\text { pengasuhan sehari-hari. }\end{array}$ & $\begin{array}{l}\text { Peserta mampu } \\
\text { menyadari dan } \\
\text { memahami pentingnya } \\
\text { konsistensi dalam } \\
\text { pelaksanaan pengasuhan } \\
\text { terhadap anak terutama } \\
\text { dalam pembentukan } \\
\text { perilaku. }\end{array}$ \\
\hline
\end{tabular}




\begin{tabular}{|c|c|c|}
\hline $\begin{array}{l}\text { "Ibu } \\
\text { teladan } \\
\text { anak } \\
\text { idaman" }\end{array}$ & $\begin{array}{l}\text { Sesi } 10 \\
\text { Sub tema “ Keteladanan". } \\
\text { Orang tua difasilitasi untuk } \\
\text { belajar menjadi orang tua yang } \\
\text { dapat memberikan contoh } \\
\text { nyata dalam kehidupan sehari- } \\
\text { hari. Keteladanan merupakan } \\
\text { salah satu aspek penting untuk } \\
\text { orang tua dalam membentuk } \\
\text { karakter yang baik pada diri } \\
\text { anak. Pelaksanaan serta } \\
\text { penanaman aturan dan hal-hal } \\
\text { positif merupakan salah satu } \\
\text { cara untuk mencegah serta } \\
\text { mengurangi perilaku negatif } \\
\text { anak }\end{array}$ & $\begin{array}{l}\text { Peserta mampu } \\
\text { memberikan contoh bagi } \\
\text { anak-anak dalam } \\
\text { menanamkan nilai dan } \\
\text { kebiasaan-kebiasaan } \\
\text { positif. }\end{array}$ \\
\hline & $\begin{array}{l}\text { Sesi } 11 \\
\text { Refleksi } \\
\text { Pengalaman selama mengikuti } \\
\text { pelatihan } \\
\text { Posttest } \\
\text { Penutup }\end{array}$ & $\begin{array}{l}\text { Peserta memahami } \\
\text { seluruh materi yang telah } \\
\text { disampaikan selama } \\
\text { pelaksanaan pelatihan } \\
\text { pada penelitian. } \\
\text { Peserta memiliki kesiapan } \\
\text { untuk melaksanakan } \\
\text { pengasuhan positif } \\
\text { kepada anak. }\end{array}$ \\
\hline
\end{tabular}

\section{Metode pengambilan data}

Alat ukur untuk mengukur efikasi pengasuhan pada penelitian ini menggunakan TOPSE (tools to measure parenting self efficacy). Skala stres pengasuhan yang digunakan adalah Parenting Stress Index yang dimodifikasi dari parenting stress index (PSI). Hasil uji reliabilitas menunjukkan bahwa skala TOPSE memiliki reliabilitas sebesar 0,901 sedangkan skala PSI memiliki reliabilitas sebesar 0,880.

Peneliti menggunakan kriteria pemilihan item berdasarkan korelasi item total. Item yang mencapai koefisien korelasi minimal 0,30 dianggap telah memberikan kontribusi yang baik bagi penelitian. Skala TOPSE memiliki 43 butir yang gugur setelah dilakukan penghitungan korelasi butir dan skala PSI memiliki 24 butir.

Lembar kerja sekaligus lembar tugas rumah digunakan sebagai instrumen monitoring (pemantauan) selama penelitian dilakukan. Lembar observasi digunakan sebagai dokumentasi catatan berdasarkan pengalaman yang dilakukan selama proses 
berlangsungnya terapi. Lembar evaluasi digunakan sebagai umpan balik (feedback) mengenai materi yang diberikan, waktu yang digunakan dalam pelatihan, penampilan dan cara penyampaian materi oleh fasilitator serta penggunaan media selama pelaksanaan proses pelatihan dalam penelitian. Penyusunan lembar kerja dan lembar evaluasi disesuaikan dengan modul yang digunakan dalam pelaksanaan penelitian setiap sesi.

\section{Tabel 2.}

Rancangan Prosedur Pelaksanaan Pelatihan

\begin{tabular}{|c|c|c|}
\hline No & Kegiatan dan waktu & Keterangan \\
\hline 1. & $\begin{array}{l}\text { Pretest (sebelum sesi } 1 \\
\text { dimulai) }\end{array}$ & $\begin{array}{l}\text { Memberikan skala TOPSE dan PSI pada } \\
\text { kelompok eksperimen dan kelompok kontrol }\end{array}$ \\
\hline 2. & $\begin{array}{l}\text { Perlakuan berupa pelatihan } \\
\text { pengasuhan positif } \\
\text { (Tiga kali pertemuan dengan } \\
\text { jeda satu minggu per } \\
\text { pertemuan) }\end{array}$ & $\begin{array}{l}\text { Perlakuan hanya diberikan pada kelompok } \\
\text { eksperimen sementara kelompok kontrol hanya } \\
\text { masuk dalam waiting list }\end{array}$ \\
\hline 3. & $\begin{array}{l}\text { Posttest } \\
\text { (Setelah sesi } 3 \text { berakhir) }\end{array}$ & $\begin{array}{l}\text { Memberikan skala TOPSE dan PSI pada } \\
\text { kelompok eksperimen dan kelompok kontrol }\end{array}$ \\
\hline 4. & $\begin{array}{l}\text { Follow-up } \\
\text { (satu minggu setelah sesi } 3 \\
\text { berakhir) }\end{array}$ & $\begin{array}{l}\text { Memberikan skala TOPSE dan PSI pada } \\
\text { kelompok eksperimen dan kelompok kontrol }\end{array}$ \\
\hline
\end{tabular}

\section{Metode analisis data}

Data yang dihasilkan pada penelitian ini akan dianalisis menggunakan analisis statistik non parametrik. Analisis statistik non parametrik digunakan karena jumlah partisipan dalam penelitian ini kurang dari dua puluh orang. Teknik analisis statistik non parametrik yang digunakan adalah Mann Whitney $U$ Test. Analisis Mann Whitney U Test bertujuan untuk menguji perbedaan skor antara kelompok eksperimen dan kelompok kontrol. Data hasil observasi selama pelatihan dalam penelitian serta lembar evaluasi merupakan data tambahan yang akan disertakan dan akan dianalisis secara kualitatif

\section{Hasil}

Berdasarkan data deskriptif (Tabel 3), partisipan mengalami penurunan skor stres pengasuhan dan peningkatan skor efikasi pengasuhan. Dua partisipan mengalami kenaikan skor stres pengasuhan pada saat follow-up. Kelompok kontrol dan kelompok eksperimen mengalami penurunan rerata skor stres pengasuhan dan peningkatan skor efikasi pengasuhan saat posttest. Rerata pretest skor stres pengasuhan kelompok 
eksperimen sebesar 78,70 dan rerata posttest sebesar 50, 00. Rerata pretest skor efikasi pengasuhan ditunjukan pada kelompok eksperimen sebesar 106,9 dan rerata posttest sebesar 188,4. Rerata pretest skor stres pengasuhan kelompok kontrol sebesar 78,70 dan rerata posttest sebesar 75,00 . Rerata pretest skor efikasi pengasuhan ditunjukan pada kelompok kontrol sebesar 134,4 dan rerata posttest sebesar 137,0. Kelompok eksperimen dan kelompok kontrol mengalami penurunan rerata dan dalam skor stres pengasuhan dan peningkatan rerata dalam skor efikasi pengasuhan namun kelompok eksperimen memiliki skor lebih tinggi dalam penurunan skor stres pengasuhan dan peningkatan skor efikasi pengasuhan.

Hasil pengamatan observer dianalisisis menggunakan uji reliabilitas antar observer yaitu menggunakan intra class correlation (ICC) untuk mengetahui kesepakatan antara observer. Hasil analisis menunjukkan kesepakatan antar rater sebesar 0,735. Berdasarkan hasil analisis tersebut menunjukkan bahwa secara keseluruhan proses pelaksanaan program pelatihan pengasuhan positif untuk ibu bekerja sudah mencapai indikator keberhasilan terhadap tujuan setiap sesi intervensi pada program pelatihan pengasuhan positif pada ibu bekerja.

Berdasarkan hasil uji homogenitas, diperoleh nilai signifikansi sebesar 0,410 $(p>0,05)$. Hasil ini menunjukan bahwa kelompok eksperimen dan kelompok kontrol berada pada kondisi yang setara sebelum pelaksanaan pelatihan. Peneliti menggunakan analisis Mean Whitney $U$ Test untuk menguji hipotesis pada penelitian efektivitas program pelatihan pengasuhan positif pada ibu bekerja untuk menurunkan stres pengasuhan.

\section{Tabel 3 .}

Deskripsi Data Stres Pengasuhan Pada Kelompok Eskperimen dan Kelompok Kontrol

\begin{tabular}{|c|c|c|c|c|c|c|c|c|c|c|c|}
\hline \multirow{2}{*}{$\begin{array}{l}\text { Partis } \\
\text { ipan }\end{array}$} & \multicolumn{5}{|c|}{ Kelompok Esperimen } & \multirow{2}{*}{$\begin{array}{c}\text { Part } \\
\text { isip } \\
\text { an }\end{array}$} & \multicolumn{5}{|c|}{ Kelompok Kontrol } \\
\hline & Pre & Post & FU & $\begin{array}{l}\text { Pre- } \\
\text { Post }\end{array}$ & $\begin{array}{c}\text { Post- } \\
\text { Fu }\end{array}$ & & Pre & Post & FU & $\begin{array}{l}\text { Pre- } \\
\text { Post }\end{array}$ & $\begin{array}{l}\text { Post- } \\
\text { Fu }\end{array}$ \\
\hline NA & 78 & 32 & 34 & -46 & 2 & DS & 78 & 76 & 76 & -2 & 0 \\
\hline AN & 70 & 56 & 62 & -14 & 6 & MA & 82 & 74 & 74 & -8 & 0 \\
\hline $\mathrm{DZ}$ & 76 & 45 & 41 & -31 & -4 & FI & 84 & 80 & 78 & -4 & -2 \\
\hline DA & 87 & 42 & 50 & -45 & 8 & ME & 74 & 70 & 70 & -4 & 0 \\
\hline $\mathrm{RE}$ & 68 & 63 & 70 & -5 & 7 & DA & 81 & 78 & 74 & -3 & -4 \\
\hline $\mathrm{AE}$ & 82 & 47 & 51 & -35 & 4 & $\mathrm{AU}$ & 72 & 68 & 68 & -4 & 0 \\
\hline NW & 86 & 61 & 58 & -25 & -3 & $\mathrm{AR}$ & 77 & 72 & 72 & -5 & 0 \\
\hline DP & 79 & 47 & 44 & -32 & -3 & RY & 87 & 84 & 86 & -3 & 2 \\
\hline $\mathrm{MJ}$ & 76 & 53 & 48 & -23 & -5 & SW & 79 & 77 & 77 & -2 & 0 \\
\hline QU & 78 & 32 & 34 & -40 & -3 & EA & 73 & 71 & 71 & -2 & 0 \\
\hline
\end{tabular}


Tabel 4.

Hasil Analisis Mann Whitney U Test

\begin{tabular}{lllcll}
\hline & Kelompok & $\begin{array}{l}\text { Mean } \\
\text { Rank }\end{array}$ & Z & Sig. & Keterangan \\
\hline Pretest & $\begin{array}{l}\text { Eksperimen } \\
\text { Kontrol }\end{array}$ & $\begin{array}{l}10,60 \\
10,40\end{array}$ & 0,076 & 0,940 & Tidak signifikan \\
\hline $\begin{array}{l}\text { Gain score (Pretest- } \\
\text { Posttest) }\end{array}$ & $\begin{array}{l}\text { Eksperimen } \\
\text { Kontrol }\end{array}$ & $\begin{array}{l}15,35 \\
5,65\end{array}$ & $-3,860$ & 0,001 & Signifikan \\
\hline $\begin{array}{l}\text { Gain score (Posttest- } \\
\text { followup) }\end{array}$ & $\begin{array}{l}\text { Eksperimen } \\
\text { Kontrol }\end{array}$ & $\begin{array}{l}6.00 \\
15,00\end{array}$ & $-0,232$ & 0,816 & Tidak Signifikan \\
\hline
\end{tabular}

Perbandingan skor pretest kelompok kontrol dan eksperimen pada Tabel 4 menunjukkan nilai signifikansi sebesar 0,940 membuktikan bahwa tidak ada perbedaan yang signifikan antara skor stres pengasuhan pada kelompok eksperimen dan kelompok kontrol sebelum perlakuan (pretest). Hal ini menunjukkan bahwa kelompok eksperimen dan kelompok kontrol memiliki kondisi setara sebelum perlakuan (pretest). Perbandingan juga dilakukan pada nilai gain score kelompok eksperimen dan kelompok kontrol.

Hasil menunjukkan nilai signifikansi gain score (posttest-follow-up) sebesar 0,816 artinya tidak ada perbedaan perubahan skor stres pengasuhan yang signifikan antara kelompok kontrol dan eksperimen setelah dilakukan follow-up. rentang persentasi nilai evaluasi pelaksanaan program pelatihan pengasuhan positif untuk menurunkan tingkat stres pengasuhan pada ibu bekerja berada pada persentasi $70-92 \%$. Rata-rata penilaian aspek materi sebesar $88 \%$ Aspek fasilitator $88,4 \%$ Penilaian partisipan terhadap fasilitas yang dugunakan selama pelatihan sebesar $77 \%$.

Pada kelompok eksperimen dan kelompok kontrol terdapat perbedaan perubahaan skor stres pengasuhan yang signfikan antara sebelum dan sesudah mengikuti program pelatihan pengasuhan positif pada ibu bekerja untuk menurunkan stres pengasuhan. Program pelatihan pengasuhan positif pada ibu bekerja efektif dalam meningkatkan efikasi pengasuhan serta menurunkan stres pengasuhan pada ibu bekerja saat sebelum dan sesudah mengikuti program pelatihan pengasuhan positif.

Kelompok eksperimen dan kelompok kontrol tidak memiliki perbedaan yang siginfikan pada perbuahan skor stres pengasuhan anatara sesudah mengikuti program pelatihan pengasuhan positif pada ibu bekerja dan seminggu setelahnya. Hasil yang didapatkan menunjukkan terjadi kenaikan rerata skor stres pengasuhan setelah seminggu intervensi berakhir (follow-up) namun kenaikan tersebut tidak signifikan.

Peneliti menggunakan data observasi, wawancara serta lembar kerja untuk melakukan peninjauan dinamika serta proses belajar pada masing-masing partisipan. Uraian penjelasan di bawah ini menjelaskan mengenai gambaran proses belajar serta dinamika proses belajar masing-masing partisipian selama proses pelaksanaan pelatihan. melakukan keterlibatan secara langsung dengan anak dan menghabiskan waktu dengan lebih berkualitas dengan anak membuat kedekatan dengan anak menjadi lebih terbangun 
sehingga membantu orang tua dalam meningkatkan keyakinan dalam pelaksanaan pengasuhan.

\section{Diskusi}

Hipotesis pada penelitian adalah pelatihan pengasuhan positif dapat memengaruhi efikasi pengasuhan sehingga dapat menurunkan tingkat stres pengasuhan pada ibu bekerja yang memiliki anak usia prasekolah. Hasil analisis data menunjukkan bahwa hipotesis penelitian dapat diterima. Hal ini berarti bahwa intervensi yang diberikan sudah cukup sesuai dengan tujuan program. Hasil ini merupakan hasil dari kontribusi beberapa faktor. Faktor-faktor tersebut diantaranya dipengaruhi oleh beberapa faktor pendukung.

Penurunan tingkat stres pengasuhan dipengaruhi oleh meningkatnya faktorfaktor keyakinan ibu bekerja dalam pelaksanaan serta dalam kemampuan pengasuhan. Faktor-faktor keyakinan serta atribut pada orang tua yang mendukung rendahnya tingkat stres pengasuhan yang dikembangkan antara lain memiliki kompetensi yang tinggi sebagai orang tua, memiliki integrasi sosial baik, memiliki kedekatan emosi dengan anak, tingkat kesehatan tinggi, tidak memiliki simtom depresi, tidak mengalami pembatasan kebebasan yang kaku dalam pelaksanaan pengasuhan dan tidak frustasi dalam mempertahankan identitas diri dan mendapatkan dukungan emosi dan aktif dari orang tua lain di lingkungan (Willinger et al., 2005).

Praktik pelaksanaan pengasuhan dengan lebih terlibat dalam pengasuhan serta pelaksanaan komunikasi efektif terhadap anak dapat meningkatkan keyakinan partisipan terhadap pelaksanaan pengasuhan Hasil penelitian Willinger et al. (2005) menyebutkan bahwa kombinasi antara empati, kedekatan, kehangatan emosi, afeksi serta otonomi dengan memperkenankan anak mandiri, berkolerasi dengan rendahnya stres pengasuhan.

Hal ini salah satunya dilakukan oleh partisipan NA. Partisipan NA mengatakan bahwa perubahan dalam pelaksanaan pengasuhan terutama saat memahami anak dengan melakukan empati terhadap emosi yang dialami oleh anak membuat partisipan lebih yakin dengan kemampuan serta pelaksanaan pengasuhan. Partisipan RE mengatakan bahwa beberapa pengalaman partisipan lain membuat RE mendapatkan beberapa hal yang dapat dilakukan dalam pengasuhan RE selanjutnya dan setelah RE melakukan perubahan tersebut, RE mengatakan bahwa hal tersebut mempengaruhi keyakinan RE mengenai kemampuan dalam pelaksanaan pengasuhan terutama dalam hal keterlibatan serta keyakinan dalam pengasuhan. Efikasi diri orang tua dan stres pengasuhan mengalami perubahan yang signifikan setelah orang tua mengikuti program pelatihan pengasuhan. Efikasi diri orang tua berkaitan erat dengan stres pengasuhan. Tingkat stres pengasuhan akan mengalami penurunan apabila efikasi diri orang tua dalam hal 
pengasuhan anak meningkat. Hal tersebut tampak pada pengamatan tiga bulan setelah orang tua selesai mengikuti program pelatihan pengasuhan (Bloomfield \& Kendall, 2012).

Perubahan pada partisipan sesuai dengan penelitian Winter et al. (2012) dengan hasil bahwa pengetahuan praktik pengasuhan yang diberikan dalam program pengasuhan berpengaruh pada keterampilan pengasuhan dan kepercayaan diri orang tua dalam mengasuh anak. Bertambahnya pengetahuan pengasuhan bermanfaat untuk melatih kembali ketrampilan yang sudah dimiliki orang tua.

Penelitian ini memiliki beberapa keterbatasan baik dari sisi isi modul maupun desain penelitian. Validitas isi modul masih harus dibuktikan secara empiris melalui uji coba sehingga masih perlu dilakukan validitas isi sebelum digunakan. Dari sisi program perlu adanya sesi relapse prevention untuk mencegah terjadinya kembali stres pengasuhan yang dialami oleh partisipan. Relapse prevention model dikembangkan untuk klien yang telah mencapai abstinensi dan bertujuan untuk mempertahankan kondisi abstinen serta telah menyelesaikan terapi residensial dengan berfokus pada pendekatan praktis (Donovan \& Marlat, 2005)

Pemilihan partisipan dalam penelitian ini menggunakan metode purposive sampling sehingga sampel yang digunakan belum tentu representatif. Sampel yang belum tentu representatif menyebabkan hasil penelitian tidak dapat digeneralisasikan pada ibu bekerja yang memiliki karakteristik berbeda dengan partisipan penelitian.

\section{Kesimpulan}

Program pelatihan pengasuhan positif pada ibu bekerja efektif dalam menurunkan tingkat stres pengasuhan pada ibu bekerja. Aspek stres pengasuhan yang mengalami penurunan paling siginfikan terjadi pada aspek parent child dysfunctional interaction lalu pada aspek parental distress dan diikuti oleh aspek difficult child (child domain). Perubahan yang terjadi pada ibu bekerja setelah mengikuti program pelatihan pengasuhan positif menurut data kulitatif diantaranya adalah perubahan dalam praktik pengasuhan serta dalam pengelolaan stres pengasuhan. Perubahan dalam praktik pengasuhan antara lain keterlibatan serta pemantauan dan pembiasaan perilaku positif. Perubahan yang dilakukan dalam pengelolaan stres pengasuhan di antaranya adalah berbagi tugas dengan pasangan.

\section{Saran}

Saran bagi peneliti selanjutnya disarankan untuk menambahkan secara lebih mendetail atau lebih operasional mengenai pengelolaan stres pengasuhan pada modul serta menambahkan rencana relapse prevention pada akhir sesi untuk mencegah terjadinya spontaneous recovery dan melakukan pengendalian terhadap ancaman validitas internal. Saran bagi orang tua terutama ibu bekerja adalah dapat mengaplikasikan langkah- 
langkah pengasuhan positif yang terdapat di dalam modul sesuai dengan gaya pengasuhan masing-masing orang tua. Saran bagi praktisi maupun psikolog adalah dapat melakukan penyempurnaan terhadap modul dan menggunakan modul sebagai acuan bagi praktisi sebagai salah satu upaya pencegahan perilaku negatif pada anak di masa yang akan datang.

\section{Ucapan Terima Kasih}

Penelitian ini merupakan penelitian yang dilakukan sebagai penelitian tesis yang dilakukan pada tahun 2019. Penulis mengucapkan terimakasih pada partisipan penelitian serta pihak-pihak yang membantu dalam penelitian, Mellissa Cattalina Trisnadi dan Rolla Apnoza yang telah membantu penulis dalam pelaksanaan pelatihan sebagai salah satu tahap pengumpulan data.

\section{Kontribusi Penulis}

MFS menyusun desain penelitian serta menganalisis data. MFS bersama dengan BA menyusun, membaca kembali serta menyesuaikan dan menyetujui susunan akhir dari naskah.

\section{Konflik Kepentingan}

Penulis menyatakan bahwa tidak ada konflik kepentingan dalam penelitian, penulisan dan atau dari artikel penulisan publikasi ini.

\section{Pendanaan}

Pendanaan penelitian ini berasal dari pendanaan penulis sendiri atau pendanaan dilakukan secara mandiri.

\section{Orcid ID}

Meinita Fitriana Sari 0000-0002-6939-1877

\section{Kepustakaan}

Bloomfield, L. \& Kendall, S. (2012). Parenting self efficacy, parenting stress and child behavior before and after a parenting programme. Primary Health Care Research $\mathcal{E}$ Development, 13(4), 364-372. https://doi.org/10.1017/S14634236120000060.

Davies, D. (2011). Child development, A Practioner's guide. The Guilford Press.

Deater-Deckard, K. (2004). Parenting stress. Yale University.

Jones, T. L., \& Prinz, R. J. (2005). Potential roles of parental self efficacy in parent and child adjustment: A review. Clinical Psychology Review, (25), 341-363. https://doi.org/10.1016/j.cpr.2004.12.004

Leung, C., Sanders, M.R., Leung, S., Mak, R., \& Laun, J. (2003). An outcome evaluation of the implementation of triple p-positive parenting program ini Hongkong. Family Process, 42(4), 531-544.

Marlat, G. A., \& Donovan, D. M. (Eds.). (2005). Relapse prevention, maintenance strategies in the treatment of addictive behaviors (Edisi kedua). The Guilford Press. 
Maryanti, \& N. C. W. (2017). Hubungan antara stres pengasuhan dan penerimaan orang tua terhadap kualitas hidup pada ibu dengan anak gangguan spektrum autisme (Tesis tidak dipublikasikan). Fakultas Psikologi Universitas Gadjah Mada.

Permata, A. I. (2017). Pelatihan pengasuhan "aktif" untuk meningkatkan kualitas pengasuhan pada ibu yang memiliki anak usia dini (Tesis tidak dipublikasikan). Fakultas Psikologi Universitas Gadjah Mada.

Pouretemad, H. R., Khooshabi, K., Roshanbin, M., \& Jadidi, M. (2009) The effectiveness of group positive parenting program on parental stress of mothers of children with attention deficit/hyperactivity disorder. Archives of Iranian Medicine, 12(1), 60-68.

Pristanti, R. F. A. (2016). Validasi modul pengasuhan positif untuk meningkatkan efikasi diri ibu tunggal dalam pengasuhan anak. (Tesis tidak dipublikasikan). Fakultas Psikologi Universitas Gadjah Mada

Sanders, M.R. (1999). Triple p-positive parenting program: towards an empirically validated multilevel parenting and family support strategy for the prevention of behavior and emotional problems in children. Clinical Child and Family Psychology Review, 2(2), 71-90.

Sanders, M. R. (2008). Triple p-positive parenting program as a public mental health approach to strengthening parenting. Journal of Family Psychology, 22(3), 507-517. https://doi.org/10.1037/0893-3200.22.3.506

Sulaiman, M. R. (2017, July). Dinamika ibu pekerja di Jakarta. Artikel detik health. Diunduh dari https://health.detik.com/berita-detikhealth/d-3553252/dinamika-ibu-pekerjadi-dki-jakarta

Sumargi, A. K., \& Morawska, A. (2015b). A randomized controlled trial of the Triple Ppositive parenting program seminar series with Indonesian parents. Child Psychiatry and Human Development, 46(5), 749-761. https://doi.org/10.1007/s10578014-0517-8

Willinger, U., Diendorfer-Radner, G., Willnauer, R., Jorgl, G., \& Hager, V. (2005). Parenting stress and parental bonding. Behavioral Medicine, 31(2), 63-69. https://doi.org/10.3200/BMED.31.2.6

Winter, L., Morawska, A., Sanders, M. (2012). The knowledge of effective parenting scale (KEPS): a tool for public health approaches to universal parenting programs. The Journal of Primary Prevention, 33 (2-3), 85-97. https://doi.org/10.1007/s10935-0120268-x 